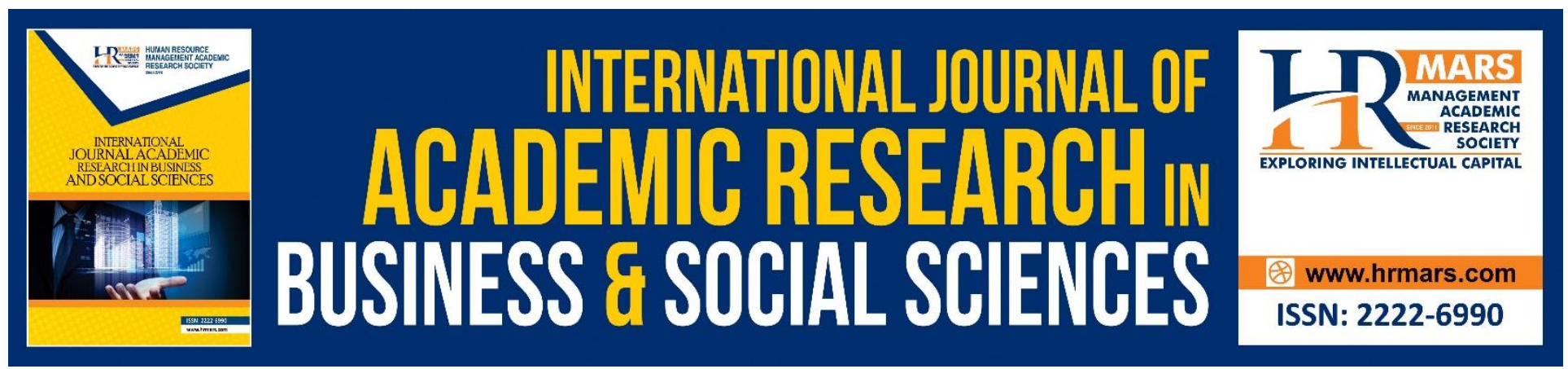

\title{
Strategic Location Considerations for Fuel Filling Stations along Thika Super Highway-Kenya
}

Peter Karanja, Catherine Wanjiru Gathitu

To Link this Article: http://dx.doi.org/10.6007/IJARBSS/v8-i8/4460

DOI: $\quad 10.6007 /$ IJARBSS/v8-i8/4460

Received: 17 July 2018, Revised: 09 August 2018, Accepted: 23 August 2018

Published Online: 31 August 2018

In-Text Citation: (Karanja \& Gathitu, 2018)

To Cite this Article: Karanja, P., \& Gathitu, C. W. (2018). Strategic Location Considerations for Fuel Filling Stations along Thika Super Highway-Kenya. International Journal of Academic Research in Business and Social Sciences, 8(8), 220-230.

\section{Copyright: (C) 2018 The Author(s)}

Published by Human Resource Management Academic Research Society (www.hrmars.com)

This article is published under the Creative Commons Attribution (CC BY 4.0) license. Anyone may reproduce, distribute, translate and create derivative works of this article (for both commercial and non-commercial purposes), subject to full attribution to the original publication and authors. The full terms of this license may be seen

at: $\underline{\text { http://creativecommons.org/licences/by/4.0/legalcode }}$

Vol. 8, No. 8, August 2018, Pg. 220 - 230

http://hrmars.com/index.php/pages/detail/IJARBSS

JOURNAL HOMEPAGE

Full Terms \& Conditions of access and use can be found at http://hrmars.com/index.php/pages/detail/publication-ethics 


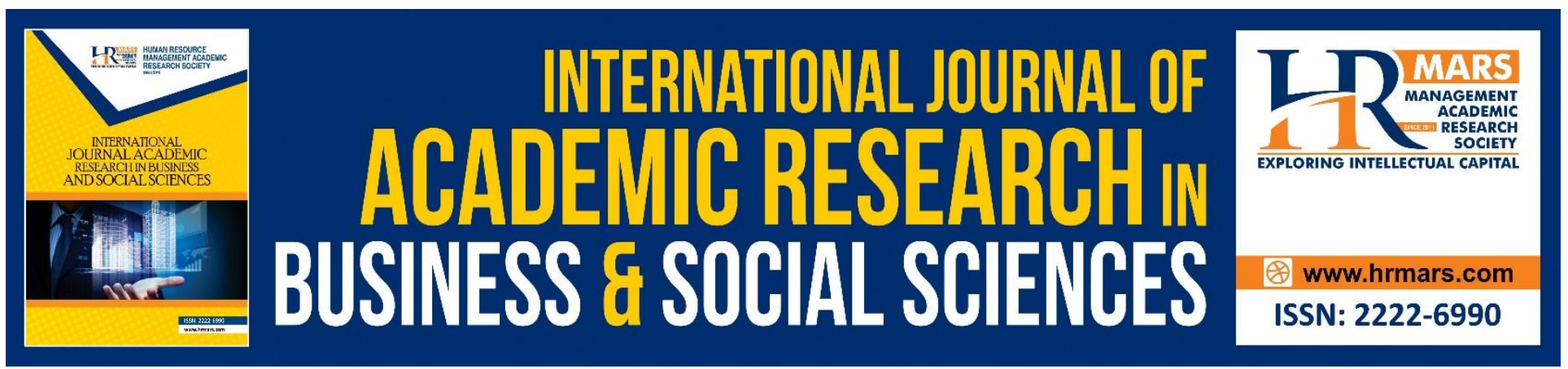

\title{
Strategic Location Considerations for Fuel Filling Stations along Thika Super Highway-Kenya
}

\author{
Peter Karanja \\ Email: bunyore@gmail.com \\ Catherine Wanjiru Gathitu \\ Kirinyaga University- Kerugoya Kenya \\ Email: mainacate2015@gmail.com
}

Jomo Kenyatta University of Agriculture and Technology Kenya.

Abstract

This research work was conducted along the Thika Superhighway in Kenya. The highway starts from Nairobi CBD and extends for about $40 \mathrm{~km}$ to another major town called Thika. For the sake of objectivity, this research was conducted and traced the location of petrol stations beyond Thika town for a further $50 \mathrm{~km}$ to another important nodal point called Makutano (Swahili for Junction) beyond which the roads become less busy. In total, the distance of interest along this busy road was approximately $90 \mathrm{~km}$. There were in total 25 petrol stations, among which 18 were located on the left hand side and 7 on the right hand side of the road as one travelled away from the CBD and this formed the target population for this research work. Due to this manageable target population, census on all the petrol stations was conducted. The basic data collection tool was a questionnaire which was self administered. out of the 25 questionnaires distributed, 23 were picked up well filled and hence used for data analysis, representing a success rate of $88 \%$. The respondents were the station management personnel. The main strategic location factors of interest were availability and cost of land, customer convenience and lastly chance. After analysis of data, it came out clearly that considerations on customer convenience played the greatest role followed by cost and availability of land and lastly chance. This was in line with the expectations since given the facts that in Kenya motorists keep to the left, and that the Thika Superhighway has a wall barrier between the left and right roads. Presence of large scale plantations on some sections of the road also played a major role in determining location of the fuel stations by limiting their presence on their sides of the road. Chance was found to play a less significant role because most of the petrol stations have been established long after the highway was built.

Keywords: Strategic Considerations, Thika Superhighway, Petrol Stations 
INTERNATIONAL JOURNAL OF ACADEMIC RESEARCH IN BUSINESS AND SOCIAL SCIENCES

Vol. 8, No. 8, August 2018, E-ISSN: 2222-6990 @ 2018 HRMARS

\section{Introduction}

Filling Station, Petrol station, gas station or petroleum outlet is defined as any land, building or equipment used for the sale or dispensing of petrol or oil for motor vehicles or incidental thereto and includes the whole of the land, building or equipment whether or not the use as a petrol station is the predominant use or is only a part thereof (Mohammed et-al 2014) Petrol filing stations serve the purpose of refueling by motorists, for minor to major motor vehicle maintenances, shopping and as resting places before resuming journeys among others. They are therefore to be found along major roads where there is sizeable traffic flow. There are generally more petrol filing stations in urban than in rural areas for the simple reason that there is more traffic flow in the urban than rural areas. The petrol filling stations come in all manner of types and sizes; from well-known multi-nationals to little known local service providers, but all serve the same purpose and their customers do value their services.

In Kenya, the motor traffic moves keeping to the left side of the road and therefore almost all motor vehicles are right handed, just as would be found in most countries that comprised the former British colonies. Then there is a major road known as Thika Super Highway which is a dual carriage way with a maximum of five lanes on either side of the road in some of its sections. The road experiences heavy traffic throughout the day and night. This road links the city of Nairobi with the northern and eastern areas of the country and extends for about $40 \mathrm{Kms}$ to another major town known as Thika which marks a major turn off to the eastern part of the country to places such as Garissa. From Thika, the lanes on either side of the road reduce to only two for about $20 \mathrm{kms}$ to another major nodal point known as Kenol, with a turn off to Murang'a town and other Central Kenya regions. Then the road becomes a single lane dual carriage for the next $30 \mathrm{Kms}$ to another major junction called Makutano (Swahili for junction) that separates the traffic headed for Nyeri and beyond from that headed for Meru, Isiolo and beyond. Along this major road from Pangani (exiting Nairobi CBD) region to Makutano, there are a total of 25 petrol filling stations, a vast majority of which are located on the left hand side of the road and just a handful on the right hand side as one travels away from the city of Nairobi.

\section{Statement of Research Problem}

A casual observation along the Thika Superhighway reveals that most of the petrol filling stations are located on the left hand side of the road as one moves away from Nairobi CBD. This raises curiosity on the possible explanation(s) for that phenomenon. For real, there must be some ordering principles but for now un-recognized that govern the distribution of the fuel stations along this main road. This research work picks up from the work of Mohammed et-al (2014) which recommended as an appropriate area for further research that more studies be conducted on filling stations especially issues related to site selection and optimization. Therefore one is left wondering: how comes most of the petrol filling stations are located on the left hand side of the road and not on the other side? Are there some considerations for location of the stations or are they located just out of chance? This research therefore attempts to unearth the strategic location considerations behind this interesting phenomenon along the Thika Super Highway, Kenya. Findings of this research work would go a long way to add value to the body of knowledge on the strategic business factors that influence business location choices. 
INTERNATIONAL JOURNAL OF ACADEMIC RESEARCH IN BUSINESS AND SOCIAL SCIENCES

Vol. 8, No. 8, August 2018, E-ISSN: 2222-6990 @ 2018 HRMARS

\section{Research Objectives}

This research endeavored to realize the following objectives:

i) To identify the influence of cost and availability of land on location of petrol filling stations along the Thika Super Highway.

ii) To measure the influence of motor vehicle customer convenience on location of petrol filling stations along the Thika Super Highway.

iii) To measure influence of chance on location of petrol filling stations along the Thika Super Highway.

\section{Literature Review}

\section{Theoretical Framework}

This research work was informed by the location theories.

\section{Location Theories}

The pioneering theory was primarily concerned with explaining who produces what goods and/or services and their ideal location considerations. According to Thunen (1783-1856), whose primary concern was location of cities vis-à-vis farms, the main location considerations were the cost of land and cost of transportation. According to this theory, there are concentric circles that develop around a city which depict major economic activities being undertaken. Production of goods that need quick delivery to the markets in the city or generally those that are perishable are located in the rings closest to the city while production of others is located in the outer rings.

Then new location theories advanced after the initial Thunen theory have added other considerations such as random chance and other dynamics. Economic activities are sometimes located due to mere chance. Krugman (1991) traced location of the carpet industry in Dalton, Georgia to a chance occurrence in 1885. But other dynamics come to play and influence location considerations. For example, in cases of agglomeration of economic activities, location does not come by chance. In the San Francisco Bay location of the Silicon Valley technology cluster, chance does not play role but other dynamics.

In conclusion, the location theories put premium on convenience and cost considerations in location of economic activities. It is therefore of paramount significance to locate economic activities in places where costs are at the minimum in order to transfer the benefits to the investor and consumers. Similarly, consumer convenience plays a significant role in deciding location of economic activities. Occurrence by chance is also considered such that economic activities come by chance without much consideration of important forces such as cost of facilities, raw materials and labour.

In the context of the petrol filling stations along the Thika-Kenol-Makutano highway, it is expected that their location is strategic to the extent that motorists would find convenience in accessing them. Therefore they are located on the left hand side of the road to offer more convenience to the motorists on that side of the road, given that on Kenyan roads drivers keep it to the left. Conglomeration of the previous petrol filling stations on one side of the highway is seen also to have influenced location decisions of successive investors. Chance might have also played a role, such that would-be investors simply found themselves locating their stations on that particular side of the highway by mere coincidence. 
INTERNATIONAL JOURNAL OF ACADEMIC RESEARCH IN BUSINESS AND SOCIAL SCIENCES

Vol. 8, No. 8, August 2018, E-ISSN: 2222-6990 @ 2018 HRMARS

\section{Conceptual Framework}

The following conceptual framework is formulated from the literature review relevant to this research work.

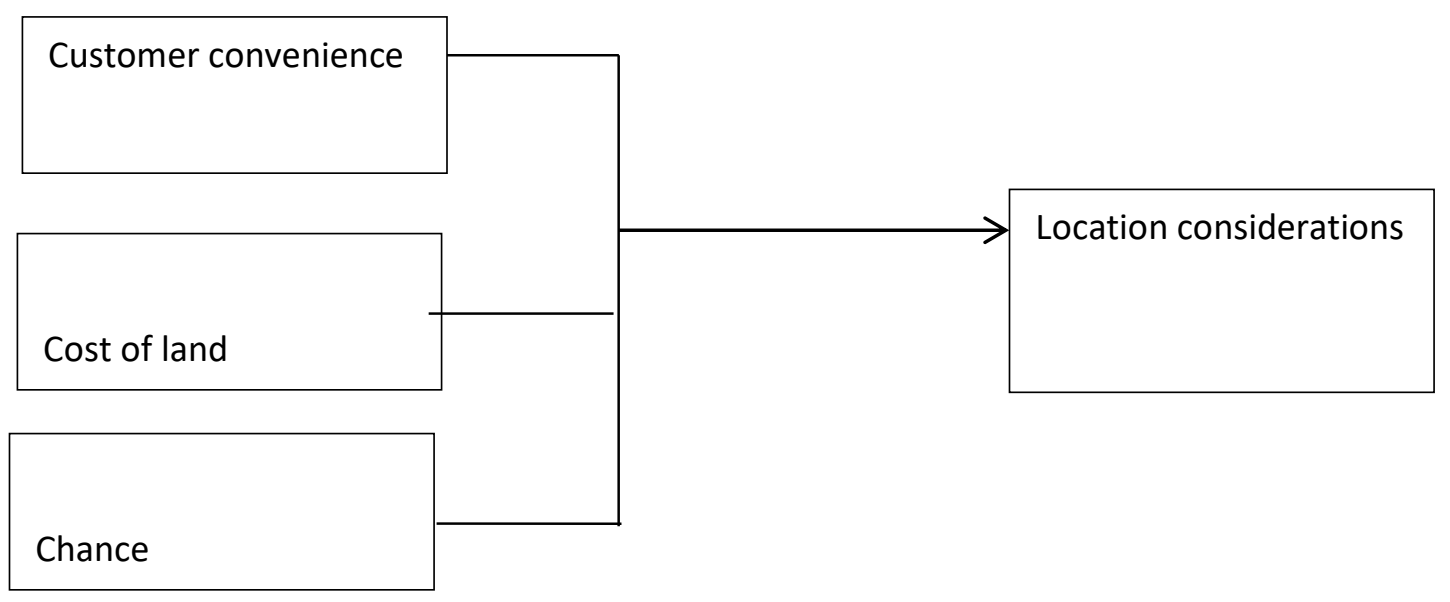

Independent variable

Dependent variable

\section{Critique of Relevant Literature}

When it comes to business decisions, customer comes first and hence a big percentage of the business decisions center on the consumer of the business goods and services. Businesses have to ask themselves some pertinent questions about the customer such as: where is she, who is she, what does she like most, how best can she be reached or reach the business, among many others. It's recommended that in the service industry, a company ought to obtain statistics on the amount of traffic or the number of pedestrians that pass by a prospective location each day.

The technological initiative of man towards the development of automobile and the discovery of petroleum triggered the building of petrol service stations at strategic locations to meet the demand of vehicle owners (Abdul et al 2009). In some jurisdictions, some of the guidelines on location of petrol filling stations touch on the traffic flow. For example, in Mauritius, functionally, petrol filling stations should be located where they are readily accessible to vehicles to avoid motorists having to make unnecessary detour for the purpose of refueling. The stations should be sited in such a way as to avoid unnecessary reversing. The function of the road, the volume and speed of traffic on the particular stretch of the road, visibility and other relevant factors should be put into consideration when selecting petrol station sites (Ministry of housing and lands 2012).

In India, the basic principle governing the location of Filling Stations as well as exit and entrance consideration is to minimize as much as possible interference with normal flow of traffic on the road. Therefore on roads having heavy traffic, it is desirable to provide one station on either side of the road at a distance of not less than 90.00 meters measured from tangent to tangent so that vehicles are not required to cross the road. It is further prescribed that filling Stations will not be allowed in any area where the traffic situation is such that it will cause obstructions in entering or leaving a station or on tight curves where visibility is not adequate (Gopalaswamy 1997). In Nigeria, among the conditions are that a petrol filling station should be sited 400 meters away from the next petrol station and that the total number of stations within $2 \mathrm{~km}$ radius of the site should not be more than four (4) including the one under construction 
The choice of a location to start a new business or to expand into new locations for an existing business is critical to the success of the entity making such decisions (Bhat et-al 2014). After all, firms incur high fixed capital and time costs in locating their businesses, and have to consider such costrelated factors as tax incentives offered by local jurisdictions, transportation infrastructure in the region, the availability and cost of human capital, and real-estate costs (Alañón-Pardo et al, (2011); Hanson et al 2011).The cost of acquiring the land and putting up the infrastructure is another important determinant of location decisions for enterprises. The cost of land is a function of a myriad of factors such as present and prospected infrastructural development and the forces of supply. In location where the level of infrastructural development is high, the cost of land is expected to be high as much and the converse would also be true.

Chance may also come to play in location decisions such that occurrence of enterprises is not following any order at all. Though a remote line of thought in present day business decision processes, it might as well be an important factor.

\section{Summary on Literature Review}

In the light of the above literature review, there are some important themes relevant to this research work that do emerge. The factor of customer convenience comes out clearly in the sense that the vast majority of the petrol filling stations are located on the left hand side of the Thika Super Highway to meet the demand for the motor vehicle customers moving away from the city presumably to further away destinations where the cost of fuel could get higher with the increase in distance. Hence, as a driver moves away from the city center, what comes to the mind is the cost of fuel, further away, hence the tendency to refuel before going further away. And since the vehicles keep to the left in this country, the petrol stations are located conveniently on the left hand side of the road. Some stretches of the land to the right hand side of the said road are owned or currently utilized by multinationals such as Delmonte and Kakuzi. This factor limits chances of location of the petrol stations on that side of the road. Chance as well may have influenced location of the petrol stations on the sites discussed herein.

\section{Methodology}

By the time of conducting this research work, there were in total twenty five (25) fuel filling stations along the section of the road of interest. The stations were assigned numbers for easier identification and data analysis. Out of these twenty five, seven were on the right hand side and eighteen on the left hand side as one travelled away from the city of Nairobi. A mapping of the station was first conducted in terms of their names and actual location sites. Attempts were made to conduct a census on all the stations by administering questionnaires to the managements. Out of the twenty five fuel stations, twenty two questionnaires were filled successfully while three fuel station managements could not be reached even after several attempts, representing a success rate of $84.6 \%$. Out of a total of seven fuel stations on the right hand side, five filled and returned the questionnaires while seventeen fuel stations on the left hand side successfully filled and returned the questionnaires. A 5point likert scale was used to quantify responses for the test items. Brief interviews were undertaken with motorists on their choice for the stations they visited and this was used to reinforce responses from station managements. The data obtained was used to make relevant analysis. 
Data Analysis and Presentation

\section{No Name of Station}

1. Shell Makuyu

2. Kahawa C

3. Mwea National

$4 \quad$ Kenol Ruiru

5. Engen KR

6. Gulf

7. Unicity

8. Maxway

9. Kareme

10. Total by pass

11. Tosha by pass

12. Shell by pass

13. Astrol

14. Cresent

15. Roysambu

16. Shell North view

17. Thome Service station

18. Total TRM

19. Shell Pangani

20. Kenol Makutano

21. Total Makuyu

22. Gulf Makuyu

\section{Location}

$\mathrm{L}$

R

L

$\mathrm{R}$

$\mathrm{R}$

$\mathrm{R}$

L

R

L

L

L

L

L

L

L

L

$L$

L

L

L

L

$\mathrm{L}$

$\mathrm{L}$
Year

2013

2002

2010

2004

2015

-

2016

2005

1995

2010

$-$

2014

2000

2003

2009

1970

2005

2007

-

2016

2014

TOTALS.

MEANS

$\mathrm{CL}=$ Cost of Land, $\mathrm{CC}=$ Customer Convenience, $\mathrm{CH}=$ Chance

Table 4.1 summary of responses from fuel station managements (means per test item)

CL $\quad$ CC $\quad$ CH

$\begin{array}{lll}3.2 & 3.3 & 3.2\end{array}$

$\begin{array}{lll}2.6 & 3.4 & 2.9\end{array}$

$\begin{array}{lll}3.4 & 2.4 & 2.9\end{array}$

$\begin{array}{lll}2.6 & 3.7 & 2.8\end{array}$

$3.4 \quad 3.8 \quad 3$

$\begin{array}{lll}1.9 & 3 & 3.1\end{array}$

$\begin{array}{lll}2.7 & 2.7 & 1.9\end{array}$

$\begin{array}{lll}2.2 & 3.2 & 2.5\end{array}$

$\begin{array}{lll}2.5 & 2.9 & 2.6\end{array}$

$\begin{array}{lll}2.6 & 3.9 & 3.2\end{array}$

$\begin{array}{lll}3 & 38 & 2.2\end{array}$

$\begin{array}{lll}3.8 & 3.4 & 3\end{array}$

$\begin{array}{lll}2.5 & 3.4 & 3.3\end{array}$

$\begin{array}{lll}2.9 & 3.1 & 3.8\end{array}$

$\begin{array}{lll}2.8 & 4.3 & 3.0\end{array}$

$3.9 \quad 3.4 \quad 3.6$

$\begin{array}{lll}2.0 & 3.1 & 2.9\end{array}$

$\begin{array}{lll}2.9 & 3.5 & 3.7\end{array}$

$\begin{array}{lll}1.8 & 2.0 & 2.6\end{array}$

$\begin{array}{lll}2.6 & 3.7 & 2.9\end{array}$

$\begin{array}{lll}2.6 & 3.8 & 3.0\end{array}$

$\begin{array}{lll}59.8 & 59.8 & 63.4\end{array}$

$\begin{array}{lll}2.7 & 3.3 & 2.3\end{array}$ 


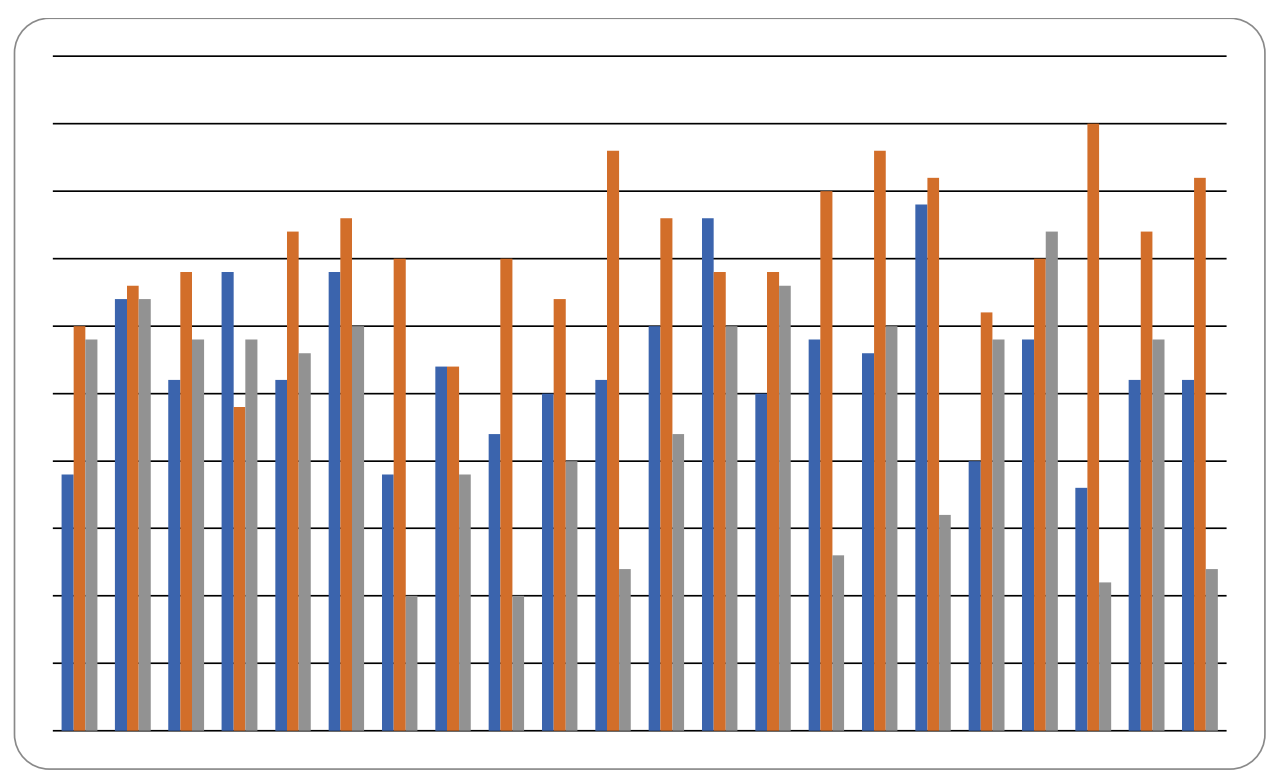

Table 4.2. comparative bar graph for responses

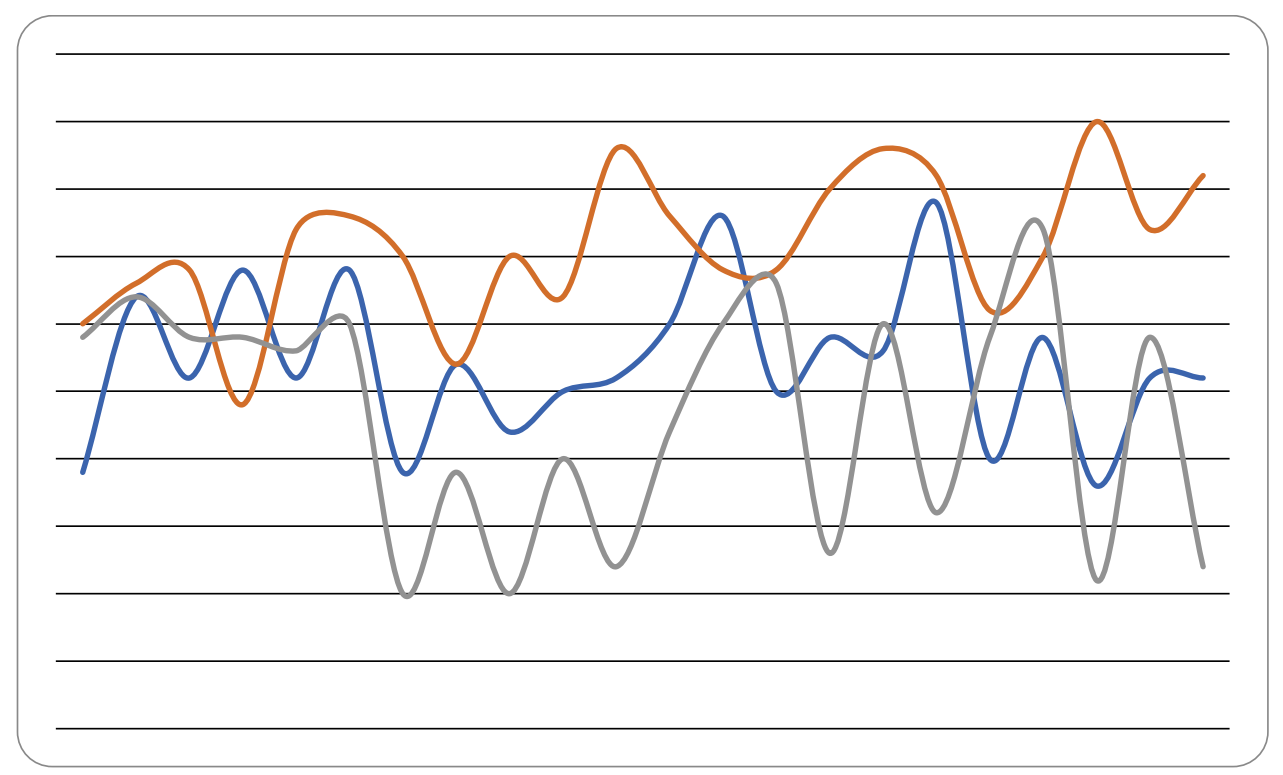

Table 4.3. Comparative line graph for responses

\section{Discussion}

This research work endeavored to find out the influence of three factors on location of fuel stations along the Thika Super Highway, Kenya, which were: Cost and availability of land, Customer Convenience and lastly Chance. Among these factors, the most influencing when informing choice for location was the customer convenience, followed by cost and availability of land and lastly chance. This means that before deciding which side of the road to locate the fuel station, whether to the left or right hand side of the road as one moved away from Nairobi CBD, convenience of the customers came top most.

Among the parameters for Customer Convenience were ease of accessibility by motorists given the fact that the road has a barrier blocking motorists from changing direction every now and then. Most 
of the fuel stations were located on the left hand side away from the CBD to target motorists heading to far flung areas of the country. It was also noted that most motorists heading away from the CBD visited fuel stations and placed orders for full or more than half of the fuel tank capacities. This went further to point out that away from the CBD, the prices of fuel went up, motorists were not sure of quality services or availability of fuel in the fuels stations, hence they preferred full or more than half tank capacities just to be sure of their safe return journeys. Those heading to the CBD mostly placed orders for less than half tank capacity, pointing to the fact that they had hopes that other stations were along the way, and that the quality of service as well as the price was likely to improve towards the CBD.

The cost and availability of land came second in strength to inform location for fuel stations. Along some sections of the road, one side of the road was occupied for long stretches by multi-national companies such as the Del Monte pine apple farms and Kakuzi avocado and livestock ranches, as well as other local establishments. Granted, this limited availability of land for putting up fuel stations along the road, and the few available stretches had prohibitive land prices. in such cases, the fuel stations tended to be located on only one side of the road, and by coincidence on the left hand side as one moved away from the CBD.

Chance came a distant third in significance when informing location considerations. It is important to note that the Thika Super Highway was only an upgrading of an already existing Thika Road that has been in use dating back to the 1950s when the British settlers occupied much of the Central Kenya Highlands. Since then the road has had very minimal changes in design plans that necessitated changing the actual route it passed. such minimal changes may have affected location of the stations as found out.

\section{Summary and Proposed areas for Further Study}

Location considerations for any enterprise are very significant, for they determine difference between a succeeding and barely surviving enterprise. Customer convenience and ease of visibility and accessibility was paramount in location of fuel stations along the Thika Super Highway in Kenya, hence most were located on the left hand side of the road away from the CBD. Availability and cost of land came second while Chance came a distance third. It's proposed that another area for future research can be the role of government regulatory mechanisms in the location factors, as well as corporate considerations since numerous stations were managed or franchised by same corporations.

\section{Acknowledgment}

The researchers wish to thank the managements of the petrol stations located along the Thika Superhighway. They were kind to fill and submit the questionnaires. They also granted researchers the chance to enter their petrol stations and freely interact with their clients.

\section{References}

Pardo, A. and Carod, A. (2011). "Agglomeration, Accessibility and Industrial Location: Evidence from Spanish Municipalities," Working paper, Facultad de Ciencias Económicas y Empresariales, Universidad Complutense de Madrid. 
INTERNATIONAL JOURNAL OF ACADEMIC RESEARCH IN BUSINESS AND SOCIAL SCIENCES Vol. 8, No. 8, August 2018, E-ISSN: 2222-6990 @ 2018 HRMARS

Chandra, B., Paleti, R. and Singh, P. (2014) A Spatial Multivariate Count Model for Firm Location Decisions. Accessed through http://www.caee.utexas.edu/prof/bhat/ABSTRACTS/Spatial_Industry_Births.pdf

Gopalaswamy, (1997) Guide to the location of gasoline (motor fuel) filling stations and filling-cumservice stations in urban areas. Town and Country Planning Organisation. New Delhi.

Andrew, H. and Rohlin, S. (2011). "Do Location-based Tax Incentives Attract New Business

Establishments?," Journal of Regional Science.

Paul, K. (1991), Geography and trade., MA: MIT Press. Cambridge

Ministry of Housing and Lands. (2012) Design, Guidance, Location and siting of filling stations Mauritius.

Mohammed, M.U., Musa, I. J,, Jeb, D.N. (2014) GIS-based analysis of the location of filling stations in metropolitan kano against the physical planning standards.

Thunen (1783-1856), accessed through: https://www.britannica.com/topic/location-theory 